\title{
Business Education: Developing Professional Competences through Gaming
}

\author{
Irina Sedelnikova \\ Production Management and Logistics Department
}

\author{
Natalya Emelyanova \\ English Language Department \\ National Research University Higher School of Economics
}

Russia

\begin{abstract}
The new paradigm in education requires new attitudes and approaches to teaching and learning practices. There is a need for more interactive technologies which will put learners in the centre of attention. The aim of this paper is to study the impact of gaming on the learning process as well as learning outcomes in business education. Students are put in a simulated business environment through a real-time business game specially designed to help develop competences relevant to the world of work. The game is based on imitation of the future business processes of manufacturing bulldozers and supply chain management in a manufacturing company. Analysis of students' opinions in the form of interviews is carried out. Participants find the game challenging and exciting, Analysis of students' opinions reveals their increased motivation and involvement. The game helps develop business-related as well as entrepreneurial competences (goal setting, decision making, teamwork etc.) relevant to the world of work. Some disadvantages of the game are also revealed.
\end{abstract}

Keyword-interdisciplinary real-time business game; a simulated business environment; learning outcomes

\section{INTRODUCTION}

Contemporary changing business environment requires new specialists who must be flexible, innovative and adaptive to new workplace. Researchers are concerned about the quality of the graduate labour market and their ability to meet the requirements of employers [6], [20]. There is an increasing mismatch between the demands of employers and skills and capabilities of graduates [7], [12]. Many businesses today demand effective teamwork, they need to add value to their customers, reach business objectives. There is a demand for 'core', or personal transferable skills, such as the ability to cooperate, communicate, and solve problems [2]. So there is a demand for specialists with the competences relevant to the world of work. A competence is defined as the ability of the learner to put skills and knowledge into action [11].

The competence-based model of learning in Higher Education is related to a constructivist approach which assumes that the teacher should create an environment in which learners are encouraged to take responsibility for their own learning, create their own view of the world, make their own discoveries, solve problems [9], [14]. Thus, "the objective of education is no longer simply to convey a body of knowledge, but to teach how to learn, problem-solve and synthesize the old with the new" [3].

The new paradigm in education requires new attitudes and approaches to teaching and learning practices. Using innovative strategies can help educate knowledgeable and competitive specialists able to meet the challenge.

There are a number of new technologies that can be used to make the learning process more student-centred. One of them is gaming. Active participation of students in the learning process and the emphasis on the quality of learning outcomes has the potential to deepen students' knowledge and enrich their learning experience [15].

The aim of this paper is to study the impact of gaming on the learning process as well as learning outcomes in business education.

\section{LITERATURE REVIEW}

Quite a few studies have been made on game-based learning, however, there is no agreement among researchers as to the impact of gaming on educational outcomes.

Lack of theoretical studies as well as lack of empirical research on the topic leads to the fact that gaming as a tool in fostering educational outcome lags behind and requires additional research [24].

Studies on gaming and its impact on learning outcomes mainly concern virtual games. Researchers are trying to investigate the learning effectiveness of games in educational settings [8],[16]. [19] as well as integrate games in higher education [23].

A number of scholars agree that using games in educational settings has positive impacts on student learning and motivation [8], [10], [19] which makes students more interested and involved in the process of learning. Motivation in the learning process can be guided internally or externally. It means that students can have intrinsic motivation which comes from the activity itself because it is interesting or enjoyable while extrinsic motivation can come from outside - teachers, peers, instructors [5]. Active participation in the process, especially interactive activities, is a driving force that will make students interested in the process and will have a great impact on their development and learning outcomes. Students not only prefer simulations and games over other methods of 
teaching, but tend to retain the information longer than if taught in conventional ways [17].

However, other researchers are somewhat critical about gaming and learning [1] express concerns about the appropriateness of game-based approach for adult learners, as well as difficulty in designing such games, their high cost and lack of interactivity [22].

Researchers identify two types of academic games: simulation games and non-simulation games [4]. Simulation game is the one in which participants are provided with a simulated environment in which to play. These games are meant to provide students with insight into the process or event from the real world which is being simulated [4]. It is the use of simulation games which holds the most promise as a truly dynamic educational tool [18].

Simulation and gaming, whether computer based or not, can be a powerful tool when used properly and in the right setting. They help students actually experience a system or problem and not just read or hear about it [18].

Both virtual and real-time games should have their place in educational settings if properly organised. The game motivates student engagement in the learning process through interacting and communicating in a simulated business reality. It creates an effective leaning environment in which learners can practice their business-related as well as entrepreneurial skills.

\section{METHODOLOGY}

A real-time business game was specially designed to put students in a simulated business environment to help them apply their knowledge and skills acquired in the process of studying. The game is different from similar games of the kind in that it does not only create a product and offers it for sale. Students had to participate in the whole production process of the product. The game is based on imitation of the future business processes of manufacturing bulldozers and supply chain management in a manufacturing company. The product (a bulldozer) is assembled from certain parts with the use of Lego bricks.

This is an interdisciplinary game as it covers different subject areas. Students had to perform a number of different operations in an interactive environment within a certain time limit. They face such problems as goal setting, team work, they have to make forecasts about the demand for their future product, behaviour of competitors, market trends. They learn to make decisions in conditions of uncertainty, formulating their expectations about customer needs and developments in the market. They should also take into account their future costs and probable losses. At the end of the game analysis of students' opinions in the form of interviews was carried out.

\section{DESCRIPTION OF THE GAME}

The game starts with defining the demand for required material resources, purchasing them, building stocks, and finishes with traffic management of material flows in the process of technical operations for bulldozers assembly.
The participants are divided into teams of 5 people each. The teams represented a company working on the market B2B (Business to Business) manufacturing similar products. At the end of the game each team was supposed to assemble as many products as they could (according to the given instruction for assembly) within a certain time limit ( 7 minutes), depending on the number of spare parts they had purchased. The products should meet certain quality requirements and the production must be cost-effective. The aim is to 'produce' as many units of the product as possible with least probable losses.

At the beginning of the game students take on different roles: director, designer, technologist, purchase managers, suppliers, quality manager. The whole game falls into five stages.

\section{A. Stage 1 .}

Preparatory stage is supposed to last 60 minutes. During this time each team think of a name for their company, develop their trademark, formulate their mission, choose a competitive strategy according to Porter, and position themselves on the market. Students allocate roles and functions within each team. At the end of the first stage each team gives a presentation of their company using appropriate visual aids, or they may use a power point presentation if it is available. The jury give each team a score which will be counted in the final assessment of each team (a possible bonus at this stage - a winner can be allowed to sell their finished products at a higher price).

\section{B. Stage 2 .}

This stage lasts 120 minutes. Its aim is production planning, purchase of components and training staff for assembling the products. Each team is provided with two sample bulldozers, as well as instructions for assembly All team members do the following operations: study the bulldozer construction according to the instructions given, choose the flow of materials during assembly process. The team members should also think about the timing of different operations, the volume of production depending on the time for assembly, calculate the size and cost of the order for components. Their task is also to make purchases from suppliers and form stocks of components, place items for easy entry into the production process depending on the selected flow of materials. Components for assembly can be bought from two different suppliers. One of them has a limited stock of items. Suppliers A and B offer their parts at different prices which vary depending on the demand. Both suppliers should be placed in different locations to be away from the place where the game takes place. There is a probability of competitive fight among manufacturers for suppliers' resources.

Each team make their own set of decisions in these spheres of activity. At the end of this stage all teams should be fully prepared for assembly process.

\section{Stage 3 .}

This stage is supposed to last 7 minutes. By the beginning of this stage everything should be ready for assembling finished products. During a limited time teams assemble their planned volume of products from the components bought. All 
team members irrespective of their position participate in assembly.

Each team was given what-man paper of a certain colour to indicate the territory of the plant. On signal of the organisers all companies simultaneously start assembling process and after some time there comes a signal to stop the activity. As a result, each team has a certain number of finished products. Besides there may be some unfinished products and extra components which can be referred to as costs.

Participants are fined for all setbacks and violation by external supervisors, who observe the process and record all operations. The setbacks are as follows:

- fall of components and finished products to the floor will be referred to as polluting environment; if this happens, the assembly process will be stopped for 60 seconds and a specialised fine is to be paid;

- $\quad$ going beyond the edge of the playing field materials and finished products will be considered as production injuries, that is penalised by stopping production for 30 seconds and paying a fine;

- inconsistency of finished products with specifications is seen as a defect. If there is one defect the product is discounted, if there are two defects or more the product is not authorized for sale.

\section{Stage 4.}

The final stage lasts 60 minutes. Organisers determine the amount of output, remnants of components, work in progress and carry out quality control. Companies sell their bulldozers at a certain price depending on the defects in their finished products as well as their competitive position on the market (See stage 1).

Each team calculate their financial results. This can be done by using a simplified scheme. Further development of the game presupposes formation of a company's balance sheet. In this case it is necessary to introduce one more player - a financial manager, as well as give additional time for preparation of financial statements. The winning team is the one which maximizes profits after the sale of finished products.

\section{E. Stage 5.}

This stage is aimed at improving existing processes. At this stage it is necessary to analyse mistakes, setbacks and inconsistencies which have been made as well as the reasons why these have taken place. As a tool for analysis students can use Ishikawa Fishbone Diagram to make a systematic analysis of the problems arisen. Some approaches for eliminating negative factors are also developed. Each team prepares a presentation on Ishikawa Diagram.

During all stages of the game the participants are recommended to use the principle of continuous improvement, KAIZEN, which means that all participants are supposed to participate in the process of improvement. KAIZEN presupposes achieving specific targets. They are eliminating losses (time, money, material, effort), improving quality (goods, services, relationships, personal behaviour), decreasing costs of production, development, maintenance of reserves and distribution of finished products. As a result, customer satisfaction increases.

Teams are free to use any approach to the organization of production or other types of activities. The main aim of the game is to see and compare different approaches, and analyse the best one.

Total time for the game is 6 academic hours. To arrange the game it is necessary to combine three 2 -hour classes.

\section{DISCUSSION AND CONCLUSION}

The main advantage of the game is that events take place in real time frame. All participants had clearly defined roles and were motivated by peer pressure as well as outside instructors who controlled the process. Teams were given freedom of choice in terms of using any approach in the production process in the course of the game. This fostered the development of the students' analytical abilities, made them apply their creativity, generate ideas and make on-the-spot decisions. Students were encouraged by everybody's excitement and competitive environment which made them perceive the situation as real and even lose track of time.

The game fosters the development of the following competences relevant to the particular subjects: product design, product layout, assembly line (Productions/Operations Management), KAIZEN system, defect problem (Quality Management), managing supplies, planning supply chain, inventory management (Logistics), formulating the goal, preparing and giving a presentation, designing strategies, computing the required results and matching them to the plan, planning production quotas, learning from experience, meeting deadlines, planning the targets and matching them to the required results (Economics/Management).

The climax of the game is stage 3 - the assembly of the product. The time limit made this stage especially challenging, exciting and intense. The contribution of each team member was vital. Mistakes made during the previous stages (lack or surplus of the components purchased, the wrong arrangement of the technological process, lack of skills for assembling the finished product due to insufficient training of staff) could have a dramatic impact on the outcome of the game. The product to be manufactured was rather difficult, it consisted of 58 components, there might be a number of different options of assembly. The technological process could be split into different operations (combinations of nods and blocks). The choice of the right decisions on all stages of assembly as well as human factor to a great extent influenced the final result.

Moreover, due to anxiety some students were unable to arrange a smooth running of production operations: components fell on the floor (which meant polluting environment and was fined), there were inconsistencies with specification (not all details were in the right places) which meant fault production. Sometimes operations took more time than planned which resulted in unfinished production.

At the end of the game two teams got profit, the other two incurred losses. One of these teams had made the wrong 
decision about the number of components to be bought and were unable to assemble the product. The other team made a mistake in the technological process and did not meet the deadline.

The analysis of opinions of participants of the game (20-22 years old students) showed that participants found the game challenging and exciting, They felt a great deal of enjoyment and pleasure in the process of the game and interaction with others that increased their motivation and involvement.

Students highly assessed the significance of their participation in the game. This imitated reality helped participants learn how to behave in different business situations. Students communicated with peers while doing tasks, learnt to adjust and to compromise as well as to be independent and persistent in their opinions if necessary.

This game helps create an effective leaning environment which provides an opportunity for taking responsibility, making decisions and becoming aware of the learning process.

Here are some of the students' reflections on the game: Kiril: 'It was really interesting, even exciting! During the game there appeared pitfalls, unexpected problems which had to be quickly solved to outperform competitors'.

Michael: 'We were able to test in practice our skills and knowledge received at lectures and seminars, and it was like in real life'.

Natalya: 'There were so many emotions: from fear and nuisance to surprise and delight! We were so fascinated by the process and experienced by ourselves all ups and downs typical of the practice of real business'.

This real-time game overcomes the drawbacks of virtual games where the activity of participants is often questioned by researchers or the situation is perceived by participants as not real [21].

At the same time some disadvantages were also revealed. The main focus of participants was laid on internal business processes of the company. It would be desirable to supplement the game with computer modelling of the situation on the market, imitating tough competition among manufacturing companies.

Analysis of own activities, problems and strategies as well as mistakes made helped students get a better insight into what a business environment really is. It permitted learners to better realise own skills and abilities and develop critical thinking. Self-evaluation and self-assessment after the game gave students a chance to look at a distance at their own activity in a team and draw some conclusions. As a result, students learn to be responsible for their decisions and consequently for their learning. We can conclude that gaming, properly organised, activates a person's potential that triggers the development of the learners' abilities and can become a valuable tool in practising learners' business-related as well as entrepreneurial skills.

\section{REFERENCES}

[1] C. Arnseth. Learning to play or playing to learn. A critical account of the models of communication informing educational research on computer game play. The international journal of computer game research, 6, (1), December 2006, available at http://gamestudies.org/0601/articles/arnseth [accessed August 2013]

[2] N. Bennett, E. Dunne \& C. Carré "Patterns of core and generic skill provision in higher education". Higher Education, vol.37 (1), pp.71-93, January1999.

[3] D. Cogburn. Globalization, Knowledge, Education and Training in the Information Age, 1999, available at http://www.unesco.org/webworldinbfoethics\&21eng/papers [accessed January 30, 2013].

[4] DR Cruickshank "Classroom Games and Simulations". Theory into practice, vol.19(1), pp.75-80, 1980.

[5] E. L. Deci, \& R. M. Ryan. Intrinsic motivation and self-determination in human behavior. New York: Plenum, 1985. Available at: http://ru.scribd.com/doc/92701230/Deci-E-L-Ryan-R-M-1985-the-

General-Causality-Orientations-Scale-Self-Determination-in-Personality [Accessed June 2013]

[6] P. Elias and K. Purcell "SOC (HE) "A classification of occupations for studying the graduate labour market". Research Report No. 6, 2004, available at www.warwick.ac.uk/go/glmf [Accessed June 2013].

[7] A. Felstead, D. Gallie and F. Green "Job Complexity and Task Discretion: Tracking the Direction of Skills at Work in Britain", in C. Warhurst, E. Keep and I. Grugulis (eds.) The Skills That Matter, London: Palgrave, 2003.

[8] R. Garris, R. Ahlers, \& J. Driskell "Games, Motivation, and Learning: A Research and Practice Model". Simulation \& Gaming, vol. 33, (4) pp.441-467, 2002.

[9] S. Grabinger, J. Dunlap, and J. Duffield "Rich environments for active learning”. ALT-J, vol. 5, no.2: pp.5-17, 1997.

[10] J. Guy Leach, S. Tammy Sugarman Play to Win! Using Games in Library Instruction to Enhance Student Learning. University Library, Georgia State University, Atlanta, GA 30303, vol. 20 (3), pp. 99-218, 2005 .

[11] S. Humphrey. "A national skills recognition system-setting standards and establishing credentials". In Education in the 1990s: Competencies, Credentialism, Competitiveness? Canberra: AGPS, 1992.

[12] Z. King "New or Traditional Careers? A Study of UK Graduates' Preferences", Human Resource Management vol.13 (1), pp. 5-27, 2003.

[13] J. Kirriemuir \& A. McFarlane. Literature Review in Games and Learning. Bristol: Nesta Futurelab series, report 8, 2004.

[14] SM. Land, and MJ. Hannafin. "Student-centered learning environments". In Theoretical foundations of learning environments, ed. DH. Jonassen and SM. Land, Mahwah NJ: Lawrence Erlbaum Associates, pp.1-23. 2000

[15] D. Newble and R. Cannon. A Handbook for Teachers in Universities and Colleges: A Guide to Improving Teaching Methods, 3rd edition. London: Kogan and Page, 1995.

[16] S. Pillay, R. James. "Gaming across cultures: Experimenting with alternate pedagogies" Monash University, Churchill, Australia Swinburne University of Technology, Melbourne, Australia, vol. 55 (1), pp. 7-22, 2013.

[17] J. Randel, B. Morris, C. Wetzel, \& B. Whitehill "The effectiveness of games for educational purposes: A review of recent research". Simulation \& Gaming, vol.23, pp.261-276, 1992.

[18] J.Seay, "Education and Simulation" Gaming and Computers, 2011 Available at: http://seayj.people.cofc.edu/cb/simgames.html?referrer=webcluster\& [Accessed April 2013]

[19] HY Sung, GJ. Hwang "A collaborative game-based learning approach to improving students' learning performance in science courses", Computers and education, vol. 63, pp. 43-51, 2013.

[20] U. Teichler, "The Future of Higher Education and the Future of Higher Education Research", Tertiary Education and Management, vol.9 (3): pp 171-185, 2003 
[21] T. J.P. Thijssen, F. T.J. Vernooij, P. Stein. Accelerating learning through gaming? Lessons from interactive and online gaming in business and business education. Working Paper № 9 Saxion University of Applied Sciences Research Centre Business Development, 2009.

[22] N. Whittona and P. Hollins ALT-J. "Collaborative virtual gaming worlds" in Higher Education, vol. 16 (3), September, 221-229 ISSN 0968-7769 print/ISSN 1741-1629 online (c) 2008 Association for Learning Technology DOI:10.1080/09687760802526756 http://www.informaworld.com Education and Social Research Institute, Manchester Metropolitan University, Manchester, UK; University of Bolton, Bolton, UK, 2008.

[23] B. Younis \& CS. Loh. Integrating serious games in higher education programs. Paper presented at Academic Colloquium: Building Partnership in Teaching Excellence. Ramallah, Palestine, 2010. 